\title{
KONTRIBUSI PENGGUNAAN PERALATAN UKUR TANAH TERHADAP HASIL BELAJAR SURVEY DAN PEMETAAN SISWA KELAS XI PROGRAM KEAHLIAN TEKNIK KONSTRUKSI BATU DAN BETON SMK NEGERI 2 BINJAI
}

\author{
Lia Hardina Harahap ${ }^{1)}$ dan Kristian ${ }^{2)}$ \\ Kristianritonga@gmail.com
}

ABSTRAK

Penelitian ini bertujuan untuk mengetahui kontribusi Penggunan Peralatan Ukur Tanah terhadap Hasil Belajar Survey dan Pemetaan pada Siswa Kelas XI Program Keahlian Teknik Konstruksi Batu dan Beton Tahun Pelajaran 2012/2013 dengan jumlah sampel 26 orang.

Data penelitian variabel Penggunaan Peralatan Ukur Tanah (X) dijaring dengan angket, dan Hasil Belajar Survey dan Pemetaan (Y) dijaring dengan tesBerdasarkan uji coba instrumen didapat hasil : (1) variabel Penggunaan Peralatan Ukur Tanah (X) 28 soal valid, reliabilitas sangat tinggi sebesar 0,869 pada taraf signifikansi 5\%. (2) Hasil Belajar Survey dan Pemetaan (Y) 25 soal yang valid, reliabilitas yang sangat tinggi sebesar 0,875 pada taraf signifikansi

5\%.Uji normalitas dengan Kolmogorov-Smirnov masing-masing variabel penelitian didapat hasil sebagai berikut : (1) variabel Penggunaan Peralatan Ukur Tanah (X) signifikan 0,195 berdistribusi normal pada taraf signifikan 5\%. (2) Hasil Belajar Survey dan Pemetaan (Y) signifikan sebesar 0,200 berdistribusi normal pada taraf signifikan 5\%.

Hasil uji masing-masing variabel penelitian didapat hasil : (1) persamaan regresi sederhana $\mathrm{Y}$ atas $\mathrm{X}_{1}$ yaitu $\hat{Y}=13,666+3,17 \mathrm{X}$, uji kelinieran persamaan regresi sederhana $\mathrm{Y}$ atas $\mathrm{X}_{1}$ yaitu $\mathrm{F}_{\text {hit }}=16,002>\mathrm{F}_{\mathrm{tab}}=4,26$ mempunyai hubungan yang linier dan berarti pada taraf signifikansi 5\%.Hasil analisis korelasi antar variabel didapat hasil : (1) Penggunaan Peralatan Ukur Tanah (X) terhadap hasil belajar Survey dan Pemetaan (Y) yaitu $\mathrm{r}_{\text {hit }}=0,633>\mathrm{r}_{\mathrm{tab}}=0,388$ menunjukkan korelasi yang berarti pada taraf signifikasi5\%.Berdasarkan hasil penelitian ini diperoleh terdapat korelasi yang berarti antara Penggunaan Peralatan Ukur Tanah (X) terhadap hasil belajar Survey dan Pemetaan (Y).

Kata Kunci: Penggunaan Peraltan Ukur Tanah, Hasil Belajar Pengukuran Survey dan Pemetaan

\section{PENDAHULUAN}

Dalam penyelenggaraan pendidikan, sarana dan prasarana yang memadai sangat dibutuhkan. Adapun yang dimaksud dengan sarana prasarana adalah keseluruhan alat dan fasilitas yang harus ada, baik yang langsung mendukung terlaksanya program yang diselenggarakan seperti alat dan kelengkapan kegiatan belajar dan praktek. Komponen sarana prasarana sangat dibutuhkan, terlebih bahwa pelaksanaan kegiatan membutuhkan alat dan fasilitas yang dapat mempelancar proses belajar mengajar. Selain itu, peranan

Kontribusi Penggunaan Peralatan Ukur Tanah Terhadap Hasil Belajar Survey -131 
guru dalam mengajar juga merupakan hal yang sangat penting karena keterlibatan guru dalam menggunakan fasilitas dalam proses belajar mengajar. Apabila kondisi fasilitas sekolah yang kurang memadai dan sesuai dengan standar kurikulum pendidikan dan tuntutan dunia usaha dan industri.

Salah satu lembaga yang menangani pendidikan yang bertugas menciptakan tenaga kerja tingkat dasar yang memiliki pengetahuan, ketreampilan maupun sikap sebagai jurusan teknik dalam bidang keteknikan yang siap pakai terutama di dunia usaha dan industri adalah Sekolah Menengah Kejuruan (SMK). Guna mencapai tujuan diatas, pemerintah Indonesia telah banyak menempuh usaha perbaikan dalam pendidikan. Usaha perbaikan yang telah dilaksanakan diantaranya : (1) perubahan kurikulum (2) peningkatan kualitas (3) pengadaan metode pengajaran (4) penyediaan bahan pengajaran dan (5) pengembangan media-media pendidikan dan pengadaan alat-alat laboratorium dan sebagainya Adapun perbaikan yang dilaksanakan tersebut tidak sesuai yang diharapkan dikarenakan masih banyaknya penyediaan perlengkapan dan peralatan untuk sekolah kinerja guru yang kurang optimal, maka proses belajar mengajar tidak akan efektif. Oleh karena itu, untuk pencapaian tujuan dalam proses pembelajaran harus

tidak disalurkan kepada siswa-siswi. Pada umumnya Sekolah Menengah Kejuruan bertujuan untuk mempersiapkan lulusannya menjadi tenaga kerja yang mempunyai pengetahuan dan keterampilan serta sikap sebagai seorang pekerja tingkat menengah sesuai dengan bidangnya masing-masing. Namun kenyataannya, penilaian dunia lapangan kerja cenderung meragukan lulusan Sekolah Menengah Kejuruan, karena lulusan Sekolah Menengah Kejuruan kurang mampu untuk menggunakan peralatan. Adanya lulusan Sekolah Menengah Kejuruan yang kurang mampu bekerja secara langsung, karena belum terjaminnya pengetahuan dan keterampilan siswa sesuai dengan lapangan kerja yang ditawarkan oleh dunia industri merupakan indikasi dari prestasi belajar yang dimiliki siswa yang kurang baik. Inilah yang menyebabkan kualitas lulusan lulusan dari Sekolah Menengah Kejuruan masih banyak yang menggangur. Penyebab dari permasalahan tersebut adalah minimnya fasilitas yang 
dimiliki oleh sekolah.

Sejalan dengan itu, Program Keahlian Teknik Kontruksi Batu Dan Beton di SMK Negeri 2 Binjai berupaya memberikan pengetahuan dan keterampilan di bidang kontruksi dengan harapan memberikan modal bekerja kepada siswa sebagai tukang batu dan beton. Dimana SMK ini merupakan SMK Negeri yang memiliki 4 program keahlian, yaitu : Teknik Konstruksi Batu dan Beton (TKBB), Teknik Mesin Otomotif (TMO), Teknik meliputi berbagai mata pelajaran keteknikan salah satunya akan diteliti adalah Melaksanakan Pengukuran Konstruksi.

Adapun salah satu indikator untuk mengukur tingkat keberhasilan siswa dalam proses pembelajaran adalah hasil belajar. Hasil belajar diukur selama proses belajar berlangsung. Dalam proses pembelajaran, siswa kurang didorong untuk berperan aktif dalam kegiatan pembelajaran. Proses pembelajaran dalam kelas diarahkan pada siswa yang mendengar dan menerima informasi yang disajikan oleh guru. Hal ini dapat merupakan salah satu penyebab rendahnya nilai hasil belajar siswa di sekolah.

Berdasarkan observasi awal yang
Body Repair (BR), dan Teknik Komputer Jaringan (TKJ). Penelitian yang dilakukan oleh peneliti adalah khusus untuk Program Keahlian Teknik Konstruksi Batu dan Beton (TKBB). Untuk mata pelajaran yang diambil adalah Melaksanakan Pengukuran Konstruksi.

Program Keahlian Teknik Konstruksi Batu dan Beton (TKBB) merupakan program pendidikan kejuruan teknik yang melaksanakan serangkaian kegiatan belajar yang

dilakukan penulis pada tanggal 16 September 2011 lalu, bahwa hasil belajar pengukuran survey belum maksimal yang dilihat dari Daftar Kumpulan Nilai (DKN), menunjukkan bahwa nilai mata pelajaran Melaksanakan Pengukuran Konstruksi pada siswa kelas XI Program Keahlian Teknik Konstruksi Batu dan Beton (TKBB) SMK Negeri 2 Binjai dengan siswa 26 orang yang memperoleh nilai seperti yang disajikan pada tabel berikut ini :

Kontribusi Penggunaan Peralatan Ukur Tanah Terhadap Hasil Belajar Survey -133

Dan Pemetaan Siswa Kelas XI Program Keahlian Teknik Konstruksi Batu Dan Beton SMK Negeri 2 Binjai Lia hardina harahap, kristian 
Tabel Ringkasan Hasil Belajar Siswa Kelas XI TKBB

\begin{tabular}{|l|c|c|}
\hline \multicolumn{1}{|c|}{ Nilai } & Jumlah & Persentase \\
\hline D $(0-69)$ & 7 & $26,9 \%$ \\
C $(70-79)$ & 11 & $42,3 \%$ \\
B $(80-89)$ & 5 & $19,3 \%$ \\
A $(90-100)$ & 3 & $11,5 \%$ \\
\hline Jumlah & $\mathbf{2 6}$ & $\mathbf{1 0 0 \%}$ \\
\hline
\end{tabular}

Dengan standar kelulusan minimal untuk mata pelajaran Melaksanakan Pengukuran Konstruksi pada siswa Program Keahlian Teknik Konstruksi Batu dan Beton SMK Negeri 2 Binjai adalah 70. Dari hasil Daftar Kumpulan Nilai dapat dilihat masih banyaknya nilai siswa yang kurang dari $<70$. Kecenderungan belum sesuainya hasil belajar Melaksankan Pengukuran Konstruksi dipengaruhi berdasarkan penggunaan peralatan ukur tanah. Hal ini, akan berpengaruh terhadap hasil belajar Pengukuran Survey dan Pemetaan Sanjaya (2006:54) menyatakan : Ada dua keuntungan bagi sekolah bila memiliki sarana yang lengkap dalam belajar, yakni: a). Kelengkapan sarana dapat meningkatkan gairah dan motivasi guru mengajar, sarana belajar dapat digunakan untuk menyampaikan materi secara efektif dan efisien; dan b). Kelengkapan sarana dapat memberikan pilihan pada siswa untuk belajar. Siswa akan lebih mudah belajar dengan mempergunakan pendengaran dan penglihatan mereka dalam memahami sarana yang tersedia.

Dari uraian diatas maka timbullah keinginan penulis untuk mengetahui sejauh mana Kontribusi Penggunaan Peralatan Ukur Tanah Terhadap Hasil Belajar Survey dan Pemetaan Pada Siswa Kelas XI Program Keahlian Teknik Konstruksi Batu dan Beton SMK Negeri 2 Binjai Tahun Pelajaran 2011/2012.

Berdasakan latar belakang masalah seperti diuraikan diatas maka masalah penelitian ini dapat diidentifikasi sebagai berikut:

1. Masih rendahnya minat belajar siswa pada mata pelajaran Melaksanakan Pengukuran Konstruksi pada siswa kelas XI Program Keahlian Teknik Konstruksi Batu dan Beton SMK Negeri 2 Binjai.

2. Masih rendahnya pemahaman siswa pada mata pelajaran Melaksanakan Pengukuran Konstruksi pada siswa kelas XI Program Keahlian Teknik Konstruksi Batu dan Beton SMK Negeri 2 Binjai.

3. Masih rendahnya Fasilitas Peralatan Ukur Tanah yang digunakan pada SMK Negeri 2 Binjai pada mata pelajaran Melaksanakan Pengukuran Konstruksi. 
Adapun alat-alat yang merupakan bagian dari Fasilitas peralatan Ukur Tanah untuk SMK, yaitu:

a. Automotic level

Pesawat ukur ini hanya dapat berputar pada satu sumbu yaitu berputar pada arah mendatar maka alat ini disebut alat penyipat datar. Alat ukur penyipat datar sederhana terdiri dari dua tabung dari gelas yang terdiri dan dihubungkan dari pipa logam. Semuanya ini dipasang diatas statip. Alat ini digunakan untuk mengukur beda tinggi semua titik yang telah ditentukan pada areal pengukuran. Dalam pengukuran beda tinggi pesawat ditempatkan diantar patok yang telah ditentukan.

b. Statif

Adalah Tripod untuk berdirinya alat ukur Automatic Level.

c. Rambu Ukur

Adalah balok dengan ukuran seperti pe nggaris, untuk dibaca ketinggiannya pada saat pengukuran. angka nol berada di bawah. Meteran panjang sekitar 30 - 100m terbuat dari bahan yang tidak mudah memuai.

\section{d. Jalon.}

Adalah tongkat penanda ukuran untuk memudahkan bidikan atau sebagai penananda dekat titik ukuran.

e. Palu-Martil

Gunanya untuk memasang patok di atas tanah (titik ukuran dan titik bantu).

f. Waterpas.

Waterpas lebih banyak dibuat dari logam yang ringan dengan bentuk persegi. Waterpas terbuat dari kayu atau dari logam ringan (aluminium) dengan bentuk I atau persegi panjang. Panjang waterpas $50 \mathrm{~cm}-120 \mathrm{~cm}$. Kegunaan untuk mengontrol kedataran dan ketegakan bidang.

f. Unting-unting

Kegunaan unting-unting adalah untuk mengontrol tegak. Kriteria unting-unting menggunakan benang yang dipakai tidak terdapat ikatan atau sambungan. Selain itu, benang yang terbaik dan terbuat dari sisal. Bagian bawah simpul ada kelebihan antara $10-15 \mathrm{~mm}$ harus dipotong dengan korek api agar terperoleh ujung yang baik.l

h. Siku Besi

Kegunaan dan mengontrol kesikuan sudut pada pekerjaan

i. Siku-siku

Kegunaan siku-siku adalah untuk menggambar dan mengontrol kesikuan 
pekerjaan. Terbuat dari besi berlapisan galvanis. Ukuran 60 × $33 \mathrm{~cm}$

j. Benang

Dapat berupa sisal/alam (terbuat dari serat/kapuk) atau benang sintesis (nilon).

Diameter benang $1-1,5 \mathrm{~mm}$. Kegunaannya untuk penyipat datar dan meluruskan pasangan.

\section{k. Meteran}

Meteran ini digunakan untuk mengukur panjang terbuat dari kayu atau plastik. Meteran terdiri dari 10 lipatan, masingmasing lipatan $20 \mathrm{~cm}$. Kegunaannya untuk mengukur panjang, lebar, dan tinggi.

1. rol meter

Rol meter ada 2 (dua) jenis: (1) rol meter tipe 1, terbuat dari bahan kain atau baja dan panjangnya $30-50 \mathrm{~m}$. (2) rol meter tipe 2 , terbuat dari bahan baja dan panjang $2-7$ $\mathrm{m}$.

Dengan demikian fasilitas peralatan ukur tanah digunakan sebagai alat bantu untuk kemudahan dalam melaksanakan proses belajar pengukuran dasar survey. Dalam hal ini kelengkapan dapat dinyatakan dalam kualitas dan kuantitas maksudnya tersedianya alat-alat atau sumber yang memadai dapat diperlukan untuk memperoleh kenyamanan dalam melaksanakan kegiatan belajar mengajar dan mewujudkan tujuan dalam hal ini hasil belajar dalam proses belajar mengajar. Dalam kaitannya dengan kegiatan yang dimaksud di sini adalah kegiatan belajar yang mempengaruhi hasil belajar pada mata pelajaran Melaksanakan Pengukuran Konstruksi

Hasil belajar menurut teori kognitif ditandai dengan kecakapan mengemukan beberapa alternatif secara simultan, memiliki tindakan yang tepat, dapat memberikan perioritas yang berurut dalam berbagai situasi. Sementara hasil belajar menurut Bloom mencakup kemampuan kognitif, afektif, dan psikomotorik. Domain kognitif adalah knowledge (pengetahuan, ingatan) atau $\mathrm{C} 1$, comprehension (pemahaman, menjelaskan, meringkas, contoh) atau C2, application (menerapkan) atau C3, analysis (menguraikan, menentukan hubungan) atau $\mathrm{C} 4$, synthesis (mengorganisasi, merencanakan, membentuk bangunan baru) atau C5, dan evaluation (menilai) atau C6.

Dari pendapat diatas disimpulkan bahwa hasil belajar adalah penilaian pencapaian proses belajar mengajar yang dinyatakan dalam bentuk angka atau huruf yang mencerminkan hasil yang dicapai oleh seseorang dalam jangka waktu tertentu. 
Pengukuran Dasar Survey adalah pelajaran yang memberikan siswa pengetahuan dan keterampilan dalam ilmu ukur tanah. Djoko Walijatun (1999:10) menyatakan : "Ilmu ukur tanah adalah sebagian kecil dari ilmu yang lebih luas, yakni ilmu geodesi”. Lebih lanjut dinyatakan ilmu geodesi mempunyai dua maksud dan tujuan yaitu: (1) maksud ilmiah, yaitu menentukan bentuk permukaan bumi, dan (2) maksud praktis, yaitu yang mempelajari penggambaran sebagian kecil dari permukaan bumi, yang dinamakan peta.

\section{METODOLOGI PENELITIAN}

Penelitian ini dilaksanakan di SMK Negeri 2 Binjai dan dilangsungkan pada kelas XI semester genap Tahun Pelajaran 2011/2012.

Populasi dalam penelitian ini adalah seluruh siswa kelas XI TKBB di SMK Negeri 2 Binjai semester genap Tahun Pelajaran 2011/2012 yang terdiri dari dua kelas dengan jumlah orang siswa, dengan rincian kelas XI TKBB1 $=26$ orang dan XI TKBB2 $=25$ orang

Sample dalam penelitian ini diambil hanya satu kelas yaitu kelas XI TKBB1 yang berjumlah 26 orang.

Metode Penelitian adalah cara yang digunakan peneliti dalam mengumpulkan data penelitiannya. Pemilihan metode penelitian sangat ditentukan oleh beberapa hal, yaitu : objek penelitian, sumber data, waktu dan dana yang tersedia, jumlah tenaga peneliti, dan teknik yang digunakan untuk mengolah data bila sudah terkumpul. Metode yang digunakan dalam penelitian ini adalah metode deskriptif jenis studi korelasi, yang merupakan penelaah hubungan antara dua variabel atau lebih pada suatu studi atau pada suatu objek. Tujuan metode deskriptif korelasional adalah untuk mengetahui kontribusi peralatan ukur tanah terhadap hasil belajar survey dan pemetaan pada siswa XI Program Keahlian Teknik Konstruksi Batu dan Beton SMK Negeri 2 Binjai Tahun Pelajaran $2011 / 2012$

Variabel-variabel dalam penelitian ini adalah Peralatan Ukur Tanah (X) sebagai variable bebas sedangkan Hasil Belajar Survey dan Pemetaan (Y) sebagai variable terikat.

Untuk menghindari penapsiran yang menyimpang maka perlu dijelaskan definisi operasional yang berkenaan dengan 
judul penelitian ini, antara lain:

1. Hasil Belajar Survey dan Pemetaan (Y) adalah gambaran tingkat penguasaan siswa pada materi pembelajaran pemahaman pengukuran pekerjaan konstruksi gedung, bangunan air, jalan dan jembatan.

2. Peralatan Ukur Tanah (X) adalah kelengkapan alat bantu yang diperlukan siswa/i dalam melaksanakan kegiatan belajar pada materi pembelajaran

Data Peralatan Ukur Tanah (X) dijaring dengan menggunakan angket tertutup model berskala Likert yang telah dimodifikasi. Menurut pendapat Hadjar (1996:184) bahwa : (1) bentuk ini cocok bila penelitian lebih menekankan respon kelompok secara umum, (2) waktu yang diperlukan untuk meresponnya relatif singkat, (3) membentuk subjek dalam menafsirkan butir yang diajukan sehingga mengurangi salah tafsir, dan (3) lebih mudah dalam penskoran hasilnya dan lebih efisien.

Penggunaan angket tertutup model berskala Likert yang telah dimodifikasi terdiri dari 4 jawaban yang merentang dari "sangat setuju" sampai pada "sangat tidak setuju". Dimana setiap pilihan jawaban diberikan bobot nilai untuk pertanyaan positif adalah sebagai berikut : sangat mengidentifikasi perlatan pengukuran dan leveling.

Pengumpulan data dilakukan dengan cermat agar terhindar dari kesalahankesalahan yang mungkin timbul. Dalam penelitian ini instrumen yang digunakan adalah menggunakan angket dan tes. Berikut ini dikemukakan instrumen dan kisi- kisi instrumen sesuai dengan variabel yang dikaji, meliputi:

setuju $=4$, setuju $=3$, tidak setuju $=2$, dan sangat tidak setuju $=1$. Sedangkan untuk pertanyaan negatif diberi bobot nilai sebagai berikut : sangat setuju $=1$, setuju $=$ 2 , tidak setuju $=3$, sangat tidak setuju $=4$.

Instrumen hasil belajar siswa pada mata pelajaran Melaksanakan Pengukuran Konstruksi. Tes diberikan dua kali yaitu pre test dan post-test. Diberikan sebelum treatment dengan tujuan agar mengetahui kesamaan karakteristik dan kesamaan pengetahuan awal siswa. Post test diberikan setelah selesai proses pembelajaran (perlakuan) dengan tujuan untuk mengetahui hasil belajar dan selanjutnya dilakukan pengelompokan menurut tingkat kemampuan kognitifnya.

Untuk mendapatkan kemampuan siswa, maka dilakukan instrumen dalam bentuk pilihan berganda dengan empat 
pilihan yaitu satu pilihan jawaban yang benar dan tiga pilihan jawaban sebagai pengecoh. Setiap butir soal yang dijawab salah serta jawaban kosong diberi nilai (0) nol dan setiap butir soal benar diberi nilai (1) satu.

Penyusunan tes dibuat berdasarkan pada teori belajar yang meliputi semua sub pembelajaran sesuai dengan Silabus

Untuk mendapatkan data prestasi belajar ukur tanah dari siswa dengan memberikan tes keterampilan menggunakan peralatan ukur tanah pada siswa yang diambil dari hasil praktek mata pelajaran melaksanakan pengukuran konstruksi dengan menggunakan lembar penilaian praktek ukur tanah.

Dalam pelaksanaan penelitian digunakan lembar penilaian praktek ukur tanah. Aspek - aspek yang dinilai pada tes prestasi belajar ukur tanah, adalah Kerapian pakaian praktek, Ketepatan waktu hadir, Ketepatan dan kecepatan dalam memasang automatic level, Ketelitian dan ketepatan membaca hasil pengukuran, Kedisiplinan dan kehadilan dalam melaksanakan praktek

\section{HASIL PENELITIAN DAN \\ PEMBAHASAN}

Berdasarkan data yang diperoleh dari hasil penelitian dengan jumlah sampel 26 orang terdapat skor tertinggi 110 dan skor terendah 72, dengan rata - rata skor sebesar 92,0385 dan standar deviasi sebesar 12,186

Dari hasil distribusi frekuensi variabel penggunaan peralatan ukur tanah dapat digambarkan histogram distribusi skor berdasarkan frekuensi absolute pada gambar berikut

\section{Chart Title}

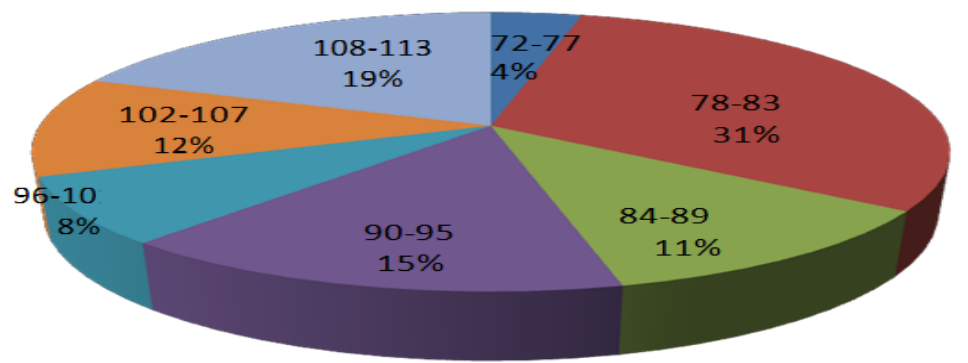

Kistogram Penggunaan Peralatan Ukur Tanah

Kontribusi Penggunaan Peralatan Ukur Tanah Terhadap Hasil Belajar Survey -139

Dan Pemetaan Siswa Kelas XI Program Keahlian Teknik Konstruksi Batu 
Berdasarkan data yang diperoleh dari hasil penelitian dengan jumlah sampel

26 orang terdapat skor tertinggi 24 dan skor terendah 6 , dengan rata - rata skor sebesar 15,500 dan standar deviasi sebesar 6.22.

Hasil Belajar Survey dan Pemetaan sebesar 0,200. Syarat agar suatu data dapat dikatakan normal adalah tar af signifikansi yang diperoleh harus lebih besar dari taraf signifikansi yang ditentukan yaitu 0.05 (Noor Juliansyah, 2011:178).

Dengan demikian dapat disimpulkan bahwa data kelengkapan Peralatan Ukur Tanah dan Hasil Belajar Survey dan Pemetaan berdistribusi normal.

Uji lineritas digunakan untuk mengetahui apakah hubungan variabel bebas $\mathrm{X}$ dengan variabel terikat $\mathrm{Y}$ linear atau tidak. Yaitu Peralatan Ukur Tanah (X) dan Hasil Belajar Survey dan Pemetaan (Y). $\mathrm{t}_{\text {hit }}=4,003>\mathrm{t}_{\mathrm{tab}}=1,706$ dengan persamaan regresi $\hat{Y}=13,666+3,17 \mathrm{X}$ adalah linier

Uji $\mathrm{F}$ digunakan untuk mengetahui sejauh mana variabel Peralatan Ukur Tanah (X) terhadap Hasil Belajar Survey dan Pemetaan (Y). Dalam pengujian ini dilakukan langkah-langkah sebagai berikut

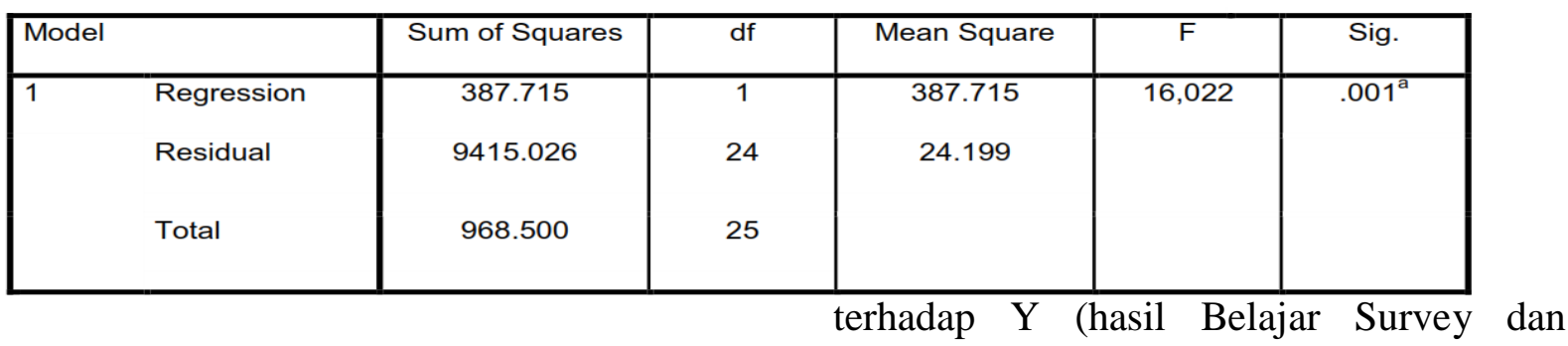

Uji $\mathrm{t}$ ini digunakan untuk mengetahui Pemetaan)

pengaruh $\mathrm{X}$ (Peralatan Ukur Tanah)

\begin{tabular}{|c|c|c|c|c|c|}
\hline \multirow[t]{2}{*}{ Model } & \multicolumn{2}{|c|}{ Unstandardized Coefficients } & \multirow{2}{*}{$\begin{array}{c}\text { Standardized } \\
\text { Coefficients } \\
\text { Beta }\end{array}$} & \multirow[b]{2}{*}{$\mathrm{T}$} & \multirow[b]{2}{*}{ Sig. } \\
\hline & B & Std. Error & & & \\
\hline $\begin{array}{l}\text { (Constant) } \\
\text { Peralatan ukur } \\
\text { tanah }(\mathrm{X})\end{array}$ & $\begin{array}{c}13.666 \\
.317\end{array}$ & $\begin{array}{l}7.350 \\
.079\end{array}$ & .633 & $\begin{array}{l}1.859 \\
4.003\end{array}$ & $\begin{array}{l}.075 \\
.001\end{array}$ \\
\hline
\end{tabular}


Berdasarkan hasil yang diperoleh dari analisis deskriptif dan setelah diadakan pengujian, maka secara umum ditemukan sejauh mana kontribusi Peralatan Ukur Tanah(X) dari siswa Kelas XI Program Keahlian Teknik Batu dan Beton SMK Negeri 2 Binjai Tahun Pelajaran 2011/2012 sebesar 81,78\%.. Berdasarkan hasil yang diperoleh dari analisis deskriptif dan setelah diadakan pengujian, maka secara umum ditemukan Hasil Belajar Survey dan Pemetaan (Y) dari siswa Kelas XI Program Keahlian Teknik Batu dan Beton SMK Negeri 2 Binjai Tahun Pelajaran 2011/2012 sebesar $32,71 \%$.

Dari hasil pengujian koefisien korelasi antara variabel Peralatan Ukur Tanah(X) dengan Hasil Belajar Survey dan Pemetaan (Y) sebesar 4,003 dan setelah dikonsultasikan dengan $t_{\text {tabel }}$ pada $\alpha$ $=0,05$ adalah 1,706. Dengan demikian hipotesis yang menyatakan terdapat hubungan positif yang berarti antara Peralatan Ukur Tanah(X) dengan Hasil Belajar Survey dan Pemetaan (Y) teruji kebenarannya. Dengan demikian hipotesis kerja (Ha) diterima dan dapat disimpulkan bahwa semakin tinggi Peralatan Ukur Tanah(X) maka semakin tinggi juga Hasil
Belajar Survey dan Pemetaan (Y).

Berdasarkan hasil dari analisis korelasi ditemukan harga koefisien korelasi sebesar 4,003 besar koefisien diterminasi $\left(R^{2}\right)=0,400$. Persamaan regresi: $\hat{Y}=13,666$ $+3,17 \mathrm{X}$ dan setelah diuji statistik F ternyata berarti pada taraf signifikasi $5 \%$.

\section{DAFTAR PUSTAKA}

Arikunto, Suharsimi. 2002. Dasar-Dasar Evaluasi Pendidikan. Jakarta : Bina

Aksara

Depdikbud.

(1999). Kurikulum

SMKJurusan Survey dan

Pemetaan.Jakarta: Depdikbud

GBPP. 2004. Kurikulum Sekolah Menengah Kejuruan-Program Produktif. Jakarta : Depdikbud

Noor Juliansyah.2012. Metodologi

Penelitian. Jakarta : Kencana

Subroto, Suryo. 1998. Sarana dan

Fasilitas belajar. Jakarta. PT Rineka Cipta.

Sudjana. 2002. Metode Satatika. Bandung : Tarsito

Walijatun, Djoko. 1999. Dasar-Dasar

Pengukuran Tanah. Semarang Erlangg

Kontribusi Penggunaan Peralatan Ukur Tanah Terhadap Hasil Belajar Survey -141

Dan Pemetaan Siswa Kelas XI Program Keahlian Teknik Konstruksi Batu Dan Beton SMK Negeri 2 Binjai Lia hardina harahap, kristian 
Kontribusi Penggunaan Peralatan Ukur Tanah Terhadap Hasil Belajar Survey -142

Dan Pemetaan Siswa Kelas XI Program Keahlian Teknik Konstruksi Batu

Dan Beton SMK Negeri 2 Binjai

Lia hardina harahap, kristian 